\title{
巨大な中空球状錯体を骨格として構築した生体分子インター フェースの開発
}

\section{Development of Biomolecular Interfaces Constructed on the Frameworks of Huge, Hollow Spherical Complexes}

\author{
東北大学原子分子材料科学高等研究機構 (WPI-AIMR); JST, ERATO, 磯部縮退 $\pi$ 集積プロジェクト 佐藤＼cjkstart宗太* \\ WPI-AIMR, Tohoku University; JST, ERATO, Isobe Degenerate p-Integration Project
}

Sota Sato*

Received March 5, 2015; E-mail: satosota@m.tohoku.ac.jp

\begin{abstract}
The clusters of biomolecules have an important role as recognition interface in living systems, where the weak molecular recognition of each biomolecular unit is efficiently enhanced by the dense assembly of the units to realize strong affinity. The mimic of these molecular designs has been explored, but the structural deviations or small number of clustered units are not satisfactory as the model of natural interfaces. In our recent projects, we synthesized biomolecular clusters by anchoring a biomolecular unit to an organic ligand followed by assembling the ligands with transition metal ions to obtain self-assembled spherical complexes. Owing to the self-assembly nature of the coordination complexes, the number of introduced biomolecular units is strictly defined, the molecular sizes are huge with the diameter of several to ten nanometers, and the synthesis is quite simple and quantitative. With the variety of sugar, DNA, or peptide clusters, we demonstrated that the huge clusters work as functional interfaces and realized the application to biomolecular or inorganic recognition and further extended to the template synthesis exploiting the recognition functions and the unique three-dimensional shape.
\end{abstract}

\section{1. はじめに}

生命現象においては、たとえば、酵素がその認識ポケ ットに小分子をとりこむことで非共有結合による分子認 識が発現し、選択的かつ高効率な化学反応が制御される 現象が知られている。このような、ホスト分子がゲスト となる基質を包み込んで独特の構造を構築し、物性や反 応が制御されるシステムは、ホストーゲスト化学として 人工系においても模倣されてきた。他の手法では実現が 困難な、あるいは実現不可能な興味深い知見がホスト ゲスト化学の手法を使って多数報告されてきているが、 それらの報告例のほとんどは 3 ナノメートル以下の分子 スケールでの現象であり、認識サイトが基質を「点」と して認識するタイプのものであった。

一方で生命現象においては、たとえば、細胞表面にお いて糖鎖がよりあつまってクラスターをなす構造が「面 =インターフェース」としてはたらき、重要な認識信号

連絡先著者名: 佐藤 宗太

連絡先 : 980-8577 仙台市青葉区片平 2-1-1

東北大学原子分子材料科学高等研究機構 (WPI-AIMR)

Tel: 022-217-6160 Fax: 022-217-6176

Corresponding Author: Sota Sato

Address: 2-1-1, Katahira, Aoba-ku, Sendai, 980-8578, JAPAN

Keywords:biomolecular interface, sugar cluster, DNA, protein encapsulation,

host-guest chemistry, self-assembly, spherical complex
として作用することが知られている。このような、非常 に多くの数の認識官能基がよりあつまることで、初めて 機能が発現する「面」の分子認識のシステムを、構造と 機能との相関を明確に示しながら展開した研究例は極め て限られる。その理由は明確であり、機能が発現する状 況において、三次元構造も考慮した全体の構造が分子レ ベルで整っており、人工合成によって自在に設計して調 製できる分子システムそのものが無かったからである。 個々の認識能は弱いものの、高密度な集積化によって機 能が発現する複雑なシステムを合理的に開発するために は、構造 - 機能の相関が明瞭に定められたシステムを対 象とし、実験的にその相関を明らかにすることを通じて、 ねらった機能を分子設計にフィードバックできる必要が ある。

本研究においては、自己組織化により構造にばらつき がない単分散な中空球状錯体を基本骨格として用い、定 量的な生体分子の官能基化による生体分子クラスターの 開発をおこなった。研究をはじめた当初、このような構 造が分子レベルで一義的に定まり、かつ直径が数ナノメ 一トルを超える巨大な錯体分子の合成そのものが挑戦的 な課題であった。合成法の改善と構造決定法の開発、さ らに、研究の進捗とオンタイムで開発された新しい装置・ 施設の利用を一体となって探求したことで、世界最大の 単一構造分子の調製法を確立できた。さらに、標的にし 
た機能に対応する生体分子を選びだし、あくまで一義構 造を有する生体分子修飾錯体をうみだすことで、数〜十 ナノメートルオーダーの生体分子クラスターがインター フェースとしてはたらく人工分子の開発を達成できた。 その独自の機能は、分子生物学的な手法あるいは無機材 料の手法など、多岐にわたる分野横断的な科学の手法に よって明瞭に描き出すことができ、個性豊かな生体分子 インターフェースの特徵を魅力的に示すことができたと 考えている。ホストーゲスト化学において、新たに「面」 で機能する一義構造の分子群をうみだし、従来法では手 の届かない巨大な分子スケールで実現された新しい認識 化学に関して、本稿ではその一端を紹介したい。

\section{2. 球状錯体の自己組織化合成}

生体分子インターフェースを構築する土台となる錯体 骨格の構築に関する研究展開を紹介する。精密な一義構 造をもつ生体分子インターフェースをうみだすために は、生体分子を化学修飾する骨格構造が一義構造であり、 かつ高効率な合成法である必要がある。さらに、分子設 計した通りに生成物が得られたことを、構造決定により 確認する必要があるが、世界最大級に大きな分子構造を、 「粒子」としてではなく「分子」として高分解能に解析 することは困難を極め、多くのブレークスルーを経て、 球状錯体の自在な合成法の確立に至つた。

2.1. 幾何学的に構造制御された対称性の高い $\mathrm{M}_{n} \mathrm{~L}_{2 n}$ 錯体 藤田グループでは、自己組織化合成に適する中程度 の強さの配位結合が得られることから、ピリジル基と パラジウム (II) イオンを鍵とする錯体合成を検討してき ている。最も単純な分子設計として、2つのピリジル基 を一定の角度に固定した剛直な二座配位子とパラジウ ム (II) イオンとの自己組織化錯体の合成が考えられる。 1994 年、 2 つの配位方向のなす角が $180^{\circ}$ の直線型配位 子を用い、平面四配位型の配位様式をとる遷移金属イ才 ンとの自己組織化をおこなうと、二次元の格子状シート

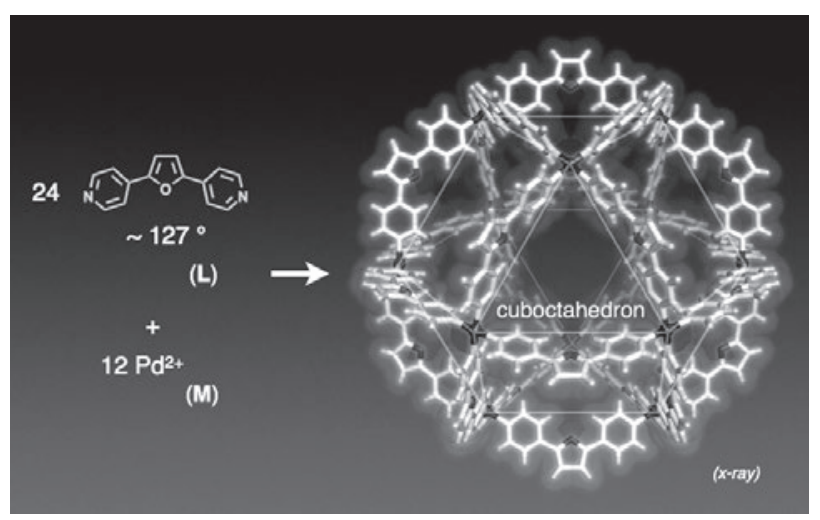

図 1. 24 個の 127 度にまがった二座配位子と 12 個のパラジウム (II) イオンとから構築された $M_{12} L_{24}$ 球状錯体の合成スキーム。
構造をもつ無限ネットワークが得られることが報告され た ${ }^{1)}$ 。さらに、2004 年になって配位子に角度をつけると、 このネットワーク構造に曲率がうまれ、三次元に閉じた 球状の錯体が定量的に得られることがみいだされた ${ }^{2)}$ この球状錯体は金属イオン（M: metal ion）が 12 個と配 位子（L: ligand）が 24 個からなる $\mathrm{M}_{12} \mathrm{~L}_{24}$ 組成の錯体で あり、金属イオンを頂点、配位子を辺とすると、対称性 が高い立方八面体型の多面体構造をもつとみなせる。各 頂点には 4 つの辺が集まり、8枚の正三角形と 6 枚の正 方形の面を有する（図 1)。

このような系をより一般化し、折れ曲がった二座配位 子とパラジウム (II) イオンとの自己組織化による生成物 の構造を考察する。配位結合の手が余らないモル比を考 えると $\mathrm{M}_{n} \mathrm{~L}_{2 n}$ 組成の錯体が生成すると予測される。さら に、ウイルスの球殼構造のように、多成分の自己組織 化においては対称性が高い構造が構築されるので、正多 面体（プラトンの立体）または半正多面体（アルキメデ スの立体) 型の錯体が構築されると仮定すると、 $n$ の值 は $n=6,12,24,30,60$ のたつた 5 種類に限定される（図 2)。一見すると、多様な、無限に近い数の構造が生成す る印象があるが、自己組織化がうまく進めば、このマジ ックナンバー $n$ で規定された、一義構造を有する生成物 だけが選択的に得られると期待される。この予測の通り、 2009 年には $n=6$ の合成例が示された 。筆者は藤田グ ループに助教として参画し、より大きな構成成分数から なる巨大錯体の合成研究にとりくんだ。

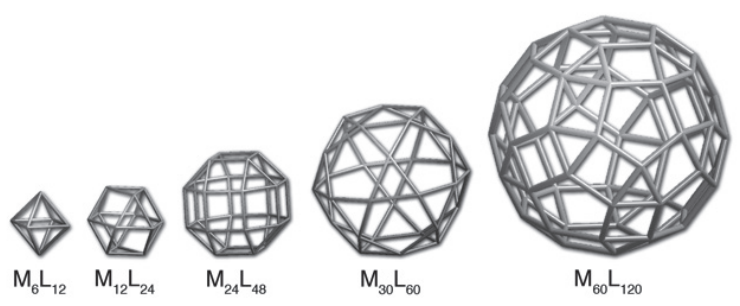

図 2. 二座配位子と平面四配位型の遷移金属イオンとから構築され ると考察された、対称性の高い $M_{n} L_{2 n}$ 組成の球状錯体。たった 5 種類の候補 $(n=6,12,24,30$, and 60) のみが予測された。

\section{2. 世界最多の構成成分数からなる $M_{24} \mathrm{~L}_{48}$ 錯体の構築}

多面体の幾何学を考えると、 $n$ の值が大きな錯体を構 築するためには、配位子の角度を広げればよい。 $\mathrm{M}_{12} \mathrm{~L}_{24}$ 錯体では、120〜 $127^{\circ}$ に曲がった配位子が用いられた ので、より大きな角度で曲がった配位子を使った検討を おこなった。ただし、実際の分子においては単純な多面 体モデルでは考慮しきれない点がある。たとえば，立 方八面体型の $\mathrm{M}_{12} \mathrm{~L}_{24}$ 錯体では、各頂点に 2 枚の正三角 形と 2 枚の正方形が交互に並ぶため、パラジウム (II) イ オンまわりの配位様式は理想的な平面四配位型とは異な る。また、出発物質や生成物の溶解度の問題から、自己 組織化が思い通りに進行しない場合もあり、実際の検討 
は（合成化学では言わずもがなであるが）トライ＆工 ラーによるところが大きかつた。

多様な配位子を設計・合成して自己組織化を検討し た結果、チオフェンを中心骨格とした $149^{\circ}$ に曲がった 配位子をパラジウム (II) イオンと混合した系において有 望な結果が得られた（図 3$)$ 。得られた錯体溶液に対し て、非常にブロードな ${ }^{1} \mathrm{H}$ NMR 信号が得られ、すなわち、 大きな構造の錯体の生成が示唆された。この錯体の拡 散係数 D、すなわち、分子が溶媒中を泳ぐ速度を DOSY NMR で見積もれば分子の大きさを推察できる。溶解度 の限界とブロード化によって信号強度が弱く、さらに巨 大構造に由来して拡散係数が小さいために、長い拡散待 ち時間による緩和減衰を補完する必要があり、高感度な 極低温 NMR プローブの利用と強い磁場勾配を用いた測 定条件の最適化が必須であった。最終的に、対流による みかけの $D$ 值の変化を試料管形状の変更によって排除 できた。得られた錯体の $D$ 值は $D=3.3 \times 10^{-11} \mathrm{~m}^{2} \cdot \mathrm{s}^{-1}(\log D$ $=-10.49)$ であり、 $\mathrm{M}_{12} \mathrm{~L}_{24}$ の $D$ 值 $(\log D=-10.30)$ より も有意に小さく、より大きな構造が生成したことが裏付 けられた。

錯体の分子量を質量分析により決定することで、 $\mathrm{M}$ と L の組成決定を検討した。配位結合からなる錯体は イオン化条件で分解しやすく、コールドスプレーイオン 化法質量分析 (CSI MS) $)^{4)}$ が適する。錯体骨格は中性の配 位子と +2 価のパラジウムイオンからなるので、CSI 法 のソフトな条件でカウンターアニオンと溶媒和した溶媒 分子が脱離すれば、錯体骨格のカチオンが容易に生成す るものと期待される。しかし、 $\mathrm{M}_{12} \mathrm{~L}_{24}$ 球状錯体の解析に 用いられたセクター型装置ではマススペクトルが得ら れなかった。錯体骨格の化学修飾やカウンターアニオ ン・溶媒の変更などスクリーニングしたが生成物のマス スペクトルを取得できなかった。国内外の十機種を超え る主要装置を使って検討を進めた結果、イオン化には問 題ないものの、生成した多価イオンを分解させずに検出 器まで導く過程に問題があり、さらにトラップを用いた 装置ではスペースチャージ効果によってスペクトルが歪 むことがわかった。最終的に、イオンを導く電位差を最 小に抑えるように条件設定し、電位差により加速されて 上昇した分子内エネルギーを取り除く機構を備えたブ ルカー・ダルトニクス社の $\operatorname{maXis}^{\mathrm{TM}}$ により、カウンター アニオンとして用いた $\mathrm{BF}_{4}^{-}$が 15 ～ 28 個脱離した $[\mathrm{M}-$ $\left.\left(\mathrm{BF}_{4}^{-}\right)_{m}\right]^{m+}(m=15 \sim 28)$ で示される一連の多価イオンが 検出できた。分解能 $3.5 \mathrm{ppm}$ 以下、分解能 $\mathrm{R}>45,000$ の 満足のいくデータが得られ、錯体の分子量は $21,946.73$ であり、その組成は $\mathrm{M}_{24} \mathrm{~L}_{48}$ であることが決定できた。 検討当時としては、唯一 $\mathrm{maXis}^{\mathrm{TM}}$ から納得できるデー夕

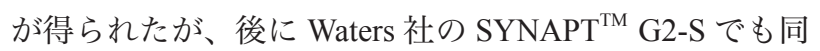
程度のスペクトルが得られた。

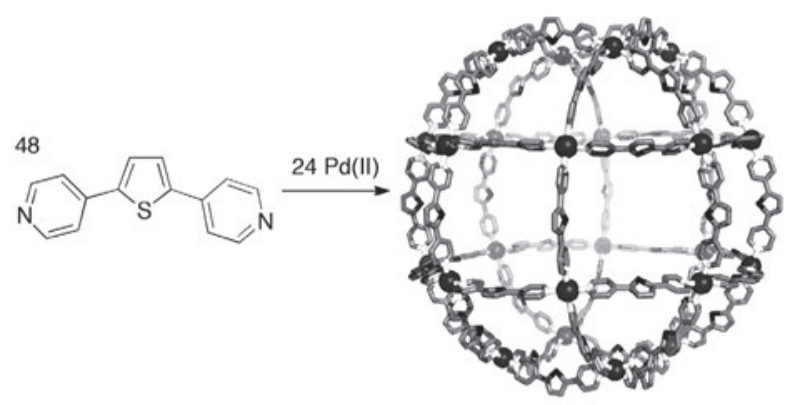

図 3. $M_{24} L_{48}$ 錯体の合成スキーム。

球状錯体の立体構造を明らかにするために、単結晶 $\mathrm{X}$ 線構造解析を検討した。DMSO とアセトニトリルを $1: 1$ の容量比で混合した溶媒を用いた錯体溶液に対し、貧 溶媒である酢酸エチルをゆっくりと蒸気拡散すること で $150 \mu \mathrm{m}$ 程度のきれいな単結晶が得られた。ループマ ウントするために結晶を溶媒ごとガラス板の上に取り出 した瞬間に溶媒の気化によって結晶性が損なわれ、各種 のクライオプロテクタントのスクリーニングや凍結温度 の最適化をおこなったが構造解析できるデー夕は得られ なかった。放射光施設を利用し、高輝度で平行性の高い X 線源を用いることで回折点を初めて観測でき、また大 面積・高感度 CCD 検出器によって結晶の照射損傷を最 小限に抑えることで、キャピラリー封入した結晶試料を 室温で測定することが可能となり、満足のいくデータ取 得に至った。構造解析の結果、外直径が $5.0 \mathrm{~nm}$ 、内直 径が $3.6 \mathrm{~nm}$ の $\mathrm{M}_{24} \mathrm{~L}_{48}$ 中空錯体であることがわかり、パ ラジウム (II) イオンを頂点とし配位子を辺とすると、斜 方立方八面体型であることがわかった。モデル化できた 錯体骨格は単位格子中の $20 \%$ の体積を占めるに過ぎず、 $80 \%$ 以上の空間は激しくディスオーダーした溶媒とカ ウンターアニオンで占められた。解析精度の指標となる $R_{1}$ は $22 \%$ と悪い数值であるが、構造を考慮すると「理 にかなって悪い」数值であると考えている。なお、その 後、更なる試料調製技術の向上と PAD 検出器を駆使し た測定ノウハウの蓄積、さらに、解析においても、擬対 称問題の解決や、場合によっては非対称ユニットに一千 を超える非水素原子が含まれる巨大構造に対する解析法 の高度化を経て、解析精度が格段に向上し、より複雑で 困難な球状錯体の結晶構造解析の手法確立を達成した。

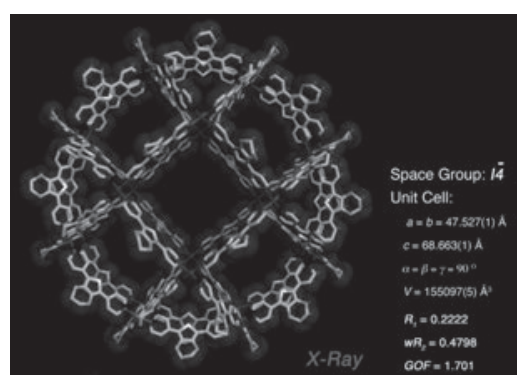

図 4. 放射光 X 線構造解析によって明らかになった、斜方立方八 面体型の $\mathrm{M}_{24} \mathrm{~L}_{48}$ 錯体の構造。 
以上のように、最初の合成反応から足かけ 4 年となっ たが、世界最多の 72 成分からなる一義構造の錯体を定 量的に合成できることがわかった ${ }^{5)}$ 。有機合成反応にお ける構造を制御する要因は、立体効果と電子効果が有名 であるが、球状錯体の自己組織化においては、幾何学的 制御の効果が支配的であり、 $\mathrm{M}_{n} \mathrm{~L}_{2 n}(n=6,12,24,30,60)$ 組成におけるマジックナンバー $n$ が存在することを明ら かにできた。各種の最先端機器と測定や解析における工 夫によって困難な問題を解決し、分子レベルで構造が制 御されていることをくまなく明らかにできた。後述する 研究においても、合成化合物はあくまで一義構造を有す るように分子設計し、個々の構造を詳細に決定すること で研究成果につながるようこだわりをもつて研究をおこ なった。

\section{3. 幾何学的制御を利用した球状錯体の合成}

幾何学制御によって合成できた様々な形状の錯体合成 について、紙面の都合上簡単に紹介する。

$\mathrm{M}_{24} \mathrm{~L}_{48}$ 錯体は $149^{\circ}$ に曲がった配位子を使い、また、 $\mathrm{M}_{12} \mathrm{~L}_{24}$ 錯体は 120 〜 $127^{\circ}$ に曲がった配位子を使ってパ ラジウム (II) イオンと自己組織化することで得られた。 このことから、 $127^{\circ} \sim 149^{\circ}$ の間に、構造が切り替わる 閾值があると考えた。そこで、それぞれ $149^{\circ}$ と $127^{\circ} に$ 折れ曲がった配位子を混合して用いて錯体合成の検討を おこなった。混合比に応じて配位子の平均角度を算出し たところ、127〜 131.4では $\mathrm{M}_{12} \mathrm{~L}_{24}$ 錯体が、133.6 149 では $\mathrm{M}_{24} \mathrm{~L}_{48}$ 錯体が得られ、質量分析の結果、それぞれ の錯体において配位子はランダムに混合されているこ とがわかった ${ }^{5}$ 。また、この角度の知見に基づいて、 $\mathrm{M}_{24} \mathrm{~L}_{48}$ 錯体が得られると期待される、それぞれ $135^{\circ}$, $143^{\circ}, 147^{\circ}$ に折れ曲がった配位子を分子設計したところ、 予想通りにすべての場合で $\mathrm{M}_{24} \mathrm{~L}_{48}$ 錯体が得られること がわかつた ${ }^{6}$ 。

ごく最近になって、 $\mathrm{M}_{12} \mathrm{~L}_{24}$ 錯体の自己組織化の過程 をNMR と質量分析で追跡したところ、中間体として $\mathrm{M}_{8} \mathrm{~L}_{16}$ 錯体と $\mathrm{M}_{9} \mathrm{~L}_{18}$ 錯体が生じることがわかってきた(図 $5)^{7,8,9)}$ 。中間体の構造は、 $112^{\circ}$ に曲がった配位子を用い て NMR とX 線構造解析によって明膫に決定できた。中 間体構造も生成物と同様に、すべての配位サイトが結

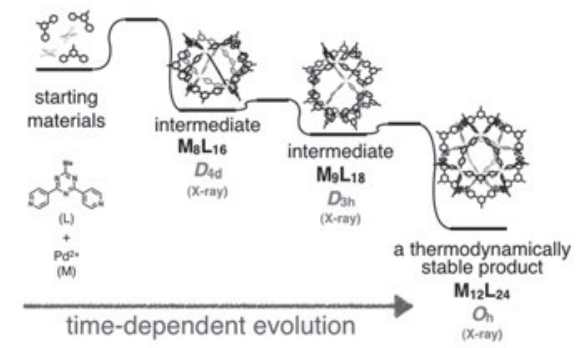

図 5. 時間展開する自己組織化の過程を実験的に捕らえた。
合に使われた一義構造であることがわかつた。 $\mathrm{M}_{n} \mathrm{~L}_{2 n}(n$ $=6,12,24,30,60)$ 組成というマジックナンバー $n$ の規則 に当てはまらない錯体が速度論的に生成することをみい だし、動的な自己組織化過程に対する新しい知見を得た。 配位子の折れ曲がり角度によって幾何学的制御が厳格 にはたらき、 $\mathrm{M}_{n} \mathrm{~L}_{2 n}$ 球状錯体が定量的に得られることを 利用し、分子設計によって自由自在に錯体骨格を制御で きることをみいだした。たとえば、大きさが 2 倍程度異 なる 2 つ配位子を連結すれば二重球構造の錯体が得ら れ ${ }^{1)}$ 、連結せずに配位子を混合すれば (擬) 切頂四面体 が得られた ${ }^{2)}$ 。また、配位子に対して追加の配位部位と なるピリジル基を導入しても、球状錯体の骨格形成は阻 害されなかった。柔軟なリンカーを介して配位部位を連 結すると、初の報告例となる星型多面体骨格が得られ 12)、また、配位部位を配位子の剛直な骨格に埋め込んだ 場合は、追加された配位部位が異種金属イオンに配位し た錯体が得られた ${ }^{13)}$ 。

パラジウム (II) イオンと同様に平面四配位型である白 金 (II) イオンを用いた場合には、配位結合がより強くな るために十分な平衡条件を達成できず、同じ条件では自 己組織化が進まなかった。しかし、トリフルオロエタノ 一ルを添加して反応条件における配位力を弱め、反応後 に減圧下でトリフルオロエタノールを除去する手法によ って球状錯体を得ることができ、酸性条件下で安定な錯 体が得られた ${ }^{14)}$ 。

\section{3. 一義構造を堅持した錯体の化学修飾}

自己組織化によって構築した球状錯体は、数十〜百に およぶ配位結合が分子の骨格を支えている。個々のピリ ジル基とパラジウム (II) イオンとの配位結合は弱いが、 多数の配位結合が一分子に集積されることで、錯体の安 定性は共有結合に匹敵するほど強くなることをみいだし ており ${ }^{15)}$ 、錯体骨格を基盤に分子設計して化学修飾すれ ばねらった通りの機能付与が可能である。

官能基化した生成物も一義構造であるためには、官 能基の導入効率が定量的でなければならない。たとえ ば $\mathrm{M}_{12} \mathrm{~L}_{24}$ 錯体では、 24 個の等価な配位子が一分子内に 含まれるため、錯体を構築した後で配位子部位を化学修 飾すると、各々の収率が 95\%であったとしても $(0.95)^{24}$ $=0.29$ と、完全に化学修飾された錯体は $30 \%$ 程度しか 得られない。そこで、あらかじめ化学修飾を施した配位 子を用いて錯体を構築することで、一義構造の生成物を 得ることにした。湾曲した配位子の内側に官能基を導入 すると、中空の球状錯体の内表面に官能基が配置される

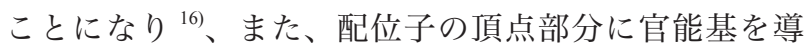
入すると球状錯体の表面に官能基が配置されることにな $ろ^{2)}$ 。 
錯体の内部と外部は、トポロジーとしては異なるもの の、実際の分子認識の様相を分子構造に基づいて考える と、区別がつかない。球状錯体そのものは、表面におよ そ1ナノメートルの正三角形や正方形の空孔があいたメ ッシュ状の構造であり、また錯体構造が巨大であるため に、錯体の内外が化学的に同じ環境にあるためである。 しかし、官能基を導入すれば、特徵的な化学的な環境を うみだすことができる。たとえば、内部に 24 本のフル オラス鎖を導入した $\mathrm{M}_{12} \mathrm{~L}_{24}$ 錯体は、有機溶媒中におい て、ナノメートルサイズの超微小なフッ素性溶媒の環境 をうみだし、複数のフッ素性の有機小分子を溶かし込む ことがわかった (図 6) ${ }^{17)}$ 。同様に、アルキル鎖を内部集 積することで疎水性小分子を溶かし込む親油性のナノ溶 媒空間を構築でき ${ }^{3)}$ 、また、芳香族分子を内部集積する ことでフラーレンを溶かし込むナノ溶媒空間を構築でき た ${ }^{19)}$ 。また、内部での官能基の異性化反応 ${ }^{21)}$ や共有結 合の生成反応 ${ }^{22)}$ 、さらに、とりこんだモノマーユニット の重合反応も可能であり ${ }^{23)}$ 、内部には十分に大きな包接 空間があり、反応場としての活用が可能である。錯体表 面の修飾においては、配位子間の間隔がおよそ $2 \mathrm{~nm}$ 程 度あいているために十分な空間があり、デンドロンのよ うな巨大な官能基も導入できた ${ }^{23)}$.

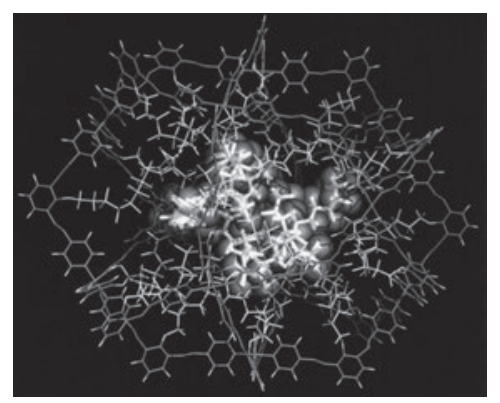

図 6. 内部にフルオロアルキル鎖を化学修飾することで、6 分子 のパーフルオロオクタンを錯体内に溶かし込むことができた。

3.1. 糖鎖インターフェースでタンパク質を丸ごと包み 込んだ錯体

このように他に類を見ない巨大で精緻な球状錯体に、 生体分子を定量的に化学修飾することで、一義構造の生 体分子クラスターがなすインターフェースを構築し、独 自構造に由来する特異な機能発現を検討した。

錯体内部にペプチドを修飾する検討をおこない、酵素 ポケットのようなキラル空間をうみだす試みにおいて、 $\mathrm{M}_{12} \mathrm{~L}_{24}$ 球状錯体の内部には 4 残基のペプチド鎖を集積で きることがわかった ${ }^{4)}$ 。配位子は 24 個あるので、錯体 内部には合計で 96 残基のペプチド鎖が内包されており、 小さめのタンパク質であれば丸ごと包接できるのではな いか、と示唆された。タンパク質の構造安定化や酵素活 性利用をめざして、タンパク質をカプセル状物質に包み 込む検討は興味を引いてきているが、人工的に合成した

一義構造の中空分子内に、タンパク質を丸ごと閉じ込め る試みは、そのような中空分子がなかったために実現で きず、初めての試みであった。

包接するタンパク質として、比較的安定性が高く、分 子シミュレーションによって内包できると見込まれる大 きさをもつことが確認できたユビキチンを選択した。C 末端を変異させてシステインとし、この残基上のチオー ル基を使って位置選択的に配位子の内側にユビキチンを 連結した ${ }^{25)}$ 。一方、親水性のタンパク質を錯体内に安定 に包み込むために、グルコースを内側に連結した配位子 を合成した。これら 2 種類の配位子を混合して、パラジ ウム (II) イオンと自己組織化をおこなった（図 7)。夕 ンパク質を分解・変性させないように穏和な反応条件 ・ 精製条件を用いるよう配慮した。得られた溶液の NMR を解析した結果、錯体由来の信号とユビキチン由来の信 号は、同じ拡散係数を示し、一体化して運動しているこ とがわかった。残念ながら質量分析において良好なスぺ クトルは得られなかったが、分子量を見積もる代替手法 として、超遠心分析を適用した。沈降速度法により、空 の錯体とユビキチン内包錯体は、それぞれ高い単分散性 を有することがわかった。さらに、沈降平衡法により重 量平均分子量を見積もると、空の錯体に比べて、ユビキ チン内包錯体では、ユビキチンに相当する分だけ分子量 が増加したことがわかった。一義的な構造をもつ、ユビ キチンを一分子だけ内包した錯体が、定量的に生成した ことが明らかになった。

23

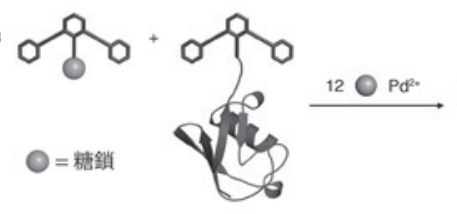

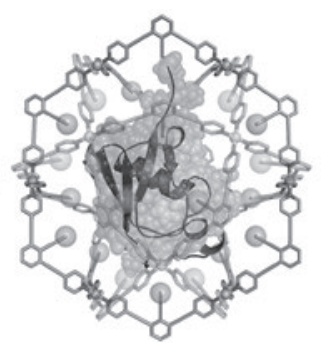

図 7. 錯体内面において 24 本の糖鎖インターフェースがつくり出 す親水性空間に、ユビキチンを丸ごと包接することができた。

一義構造を有するために単結晶を調製することがで き、ユビキチン内包錯体の放射光 X 線構造解析をおこ なうことができた。通常の解析においては、錯体骨格は 分子設計通りに $\mathrm{M}_{12} \mathrm{~L}_{24}$ 球状錯体であることがわかった が、タンパク質の構造をモデル化することはできなかつ た。しかし、単結晶を電気泳動により解析すると、結晶 中にユビキチンが含まれていることがわかり、また、結 晶のパッキング構造を考慮すると、錯体内部以外にユビ キチンが存在する空隙がないこともわかった。そこで、 空の錯体の結晶データとユビキチン内包錯体の結晶デー 夕に対して、弱い電子密度を精密化できるマキシマムエ 
ントロピー（MEM）法を適用し、電子密度のヒストグ ラムの差分解析を抏こなった。その結果、ユビキチンの 占める体積に相当する分だけ、空の錯体における溶媒分 子に対応する電子が、ユビキチンに対応する電子に置き 換わったことが明らかになった。さらに、ユビキチンに 対応する平均電子密度を分子構造にマッピングすると、 錯体分子の中央部分に電子雲が浮かび上がった。シミュ レーションモデルとの比較を通じて、錯体内表面の糖鎖 がなすインターフェースに包まれる形で、錯体中央部分 にユビキチンが丸ごと包接されている様相が明らかにな つた ${ }^{26}$ 。

3.2. 糖鎖インターフェースによる無機ナノ粒子のテン プレート合成

ユビキチンを包む糖鎖インターフェースは、ぴったり 24 分子だけの糖鎖が球状の中空ナノ空間に均等に配置 された一義構造であるという構造的な特徵をもつ。この 糖鎖を三次元のテンプレートとして無機ナノ粒子を合成 すれば、糖鎖のなす精密構造が転写されて、構造が精密 制御されたナノ粒子が得られると考えた ${ }^{27}$ 。糖鎖はシリ カ重合反応のテンプレートとなることが知られているこ とから、糖鎖を内部に化学修飾した球状錯体を合成し、 次にシリカゲル前駆体であるテトラメトキシシランを加 えてゾル - ゲル反応をおこなったところ、錯体内部での み重合反応が進行してシリカナノ粒子が得られた（図 8)。分子レベルで構造が制御されたことによって、質 量分析による分子量の決定や透過型電子顕微鏡（TEM） によるシリカナノ粒子の観察による粒径の決定ができ、 高分解能な構造決定が達成された。CSI-MS では錯体骨 格が保持されて糖鎖インターフェースに包まれたシリカ ナノ粒子全体の分子量が決定でき、またレーザー脱離イ オン化飛行時間型質量分析 (LDI-TOF-MS) ではイオン化 条件で錯体骨格が分解してシリカナノ粒子の分子量が決 定できた。加える前駆体の当量や錯体骨格の大きさに応 じて、5 千から 3 万 1 千の範囲で定量的に重合反応が進 行し、いずれも多分散度が 1.01 以下という高い単分散 性のシリカナノ粒子が得られた ${ }^{28)}$ 。この手法は酸化チ夕 ンナノ粒子合成や ${ }^{29)}$ 、シリカナノ粒子を構築したあとで
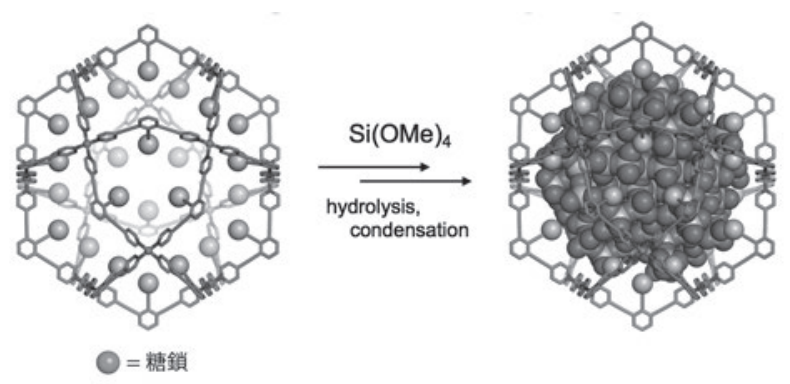

図 8. 錯体内面の糖鎖インターフェースを三次元のテンプレート となる反応場として用い、単分散の無機ナノ粒子を合成した。
酸化チタン前駆体や酸化ジルコニウム前駆体を加えるこ とでコア - シェルタイプのナノ粒子の合成にも応用する ことができ ${ }^{30}$ 、構造が精密制御された無機ナノ粒子合成 として高い汎用性をもつことが示された。

\section{3. 分子を超えた巨大なスケールで分子認識する錯体} 表面の生体分子インターフェース

中空錯体内の生体分子インターフェースはタンパク質 や無機ナノ粒子といった、1 桁代のナノメートルスケー ルの分子・物質を認識できることがわかった。錯体の表 面の生体分子インターフェースを使えば、より大きなス ケールでの分子認識にも適用できると考えた。たとえば 糖鎖インターフェースを表面に有する錯体を合成し、糖 鎖認識サイトを複数もつタンパクであるレクチンとの相 互作用を検討したところ、導入した糖鎖の種類に応じた 選択認識が発現して凝集が抢こることがわかったわ。 た、DNA 鎖インターフェースを構築した錯体では、相 補的塩基対の選択認識が発現して凝集することがわかつ た ${ }^{8)}$ 。無機物に対しても応用可能であり、シリカゲルの 重合反応を表面で㧍こなうと錯体を包むシリカの殼が得 られ、この特異な構造は焼成・還元の手順を経て錯体に 由来する酸化パラジウム (II) やパラジウム $(0)$ ナノクラ ス夕の合成に応用できた ${ }^{9}$ 。錯体内部には入りきらない 巨大な分子スケールでの生体分子や無機物に対する分子 認識を、分子設計された一義構造分子を用いて展開でき ることがわかってきた。

さらに認識対象を究極的に大きく、無限の表面にまで 拡張する検討をおこなった。無限表面の認識に必要な化 学修飾を分子設計し、特定の無機物を認識する配列のぺ プチドアプタマーの導入による無機基板の表面認識を標 的とした。酸化チタンを認識する 6 残基からなるペプチ ドである minTBP-1 (Arg-Lys-Leu-Pro-Asp-Ala) $)^{10}$ を錯体 表面に化学修飾した。この錯体溶液を酸化チタン表面に 接触させ、その相互作用を水晶振動子マイクロバラン ス $(\mathrm{QCM})$ によって解析したところ、不可逆的に強く錯 体が表面吸着されたことがわかった。 minTBP-1 単体で の吸着は可逆的で弱いことが知られており、錯体表面に 密にペプチドアプタマーを集積したことで複数のペプチ ドアプタマーが共同的に作用できるようになり、その認 識能が強化されたことを明らかにできた。さらに、酸 化チタンの単結晶を用い、原子間力顕微鏡 $(\mathrm{AFM})$ で錯 体吸着の様子を観察したところ、非常に高密度に吸着 された様子がわかった（図 9) ${ }^{11}$ 。なおごく最近、この minTBP-1 修飾錯体の大きさが DNA を巻き取るヒスト ンに近く、 $\operatorname{minTBP}-1$ に由来する正電荷を活用すること でDNAを多段階で巻き取っていく様相も AFMにより 明らかにすることができた ${ }^{13}$ 。 


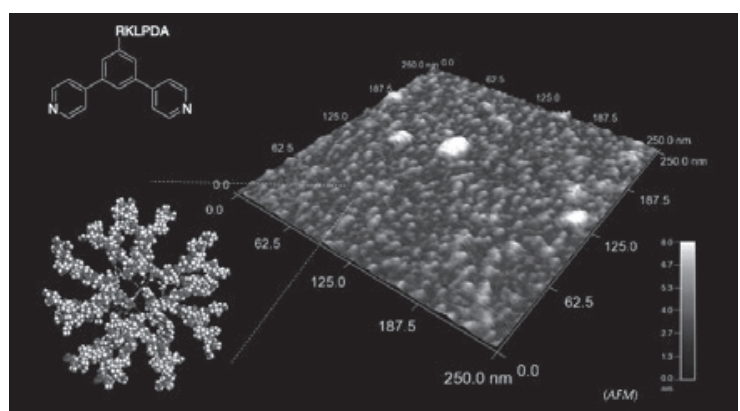

図 9. AFM 観察によってみいだされた、酸化チタン表面に高密度 吸着されたペプチドアプタマーインターフェースを有する錯体分 子。

\section{4. おわりに}

本研究では、中空球状錯体を母核に用い、錯体内外に 精密に生体分子を化学修飾することで、分子生物学的な 応用や生命現象に関連する分子認識の発現、さらに無機 材料合成や無機基板認識への応用展開を達成した。自己 組織化を駆使することで、巨大な中空球状錯体を定量的 かつ精密な構造をとるように自在に合成し、分子レベル の高分解能で興味のある構造や機能を明瞭に決定するこ とを通じて、独特の構造に由来する特異な機能を開発し た。従来法では達成困難な〜十ナノメートルの巨大な分 子スケールにおける、二次元的な「認識面」を活用した 新たな分子認識化学を開拓できたと考えている。今後、 この方法論が有機合成化学と分子生物学、材料科学とを 橋渡しすることを夢見ている。

\section{謝辞}

本研究は東京大学大学院工学系研究科応用化学専攻の 藤田 誠 教授のご指導のもとでおこなったものであ り、同教授に深く感謝申し上げます。同研究室の河野正 規博士 (現ポハン工科大学大学)、吉沢道人博士（現東 京工業大学)、村瀬隆史博士 (現山形大学) 、猪熊泰英博士、 澤田知久博士、藤田大士博士には、この研究に関する様々 な助言をいただき、共同研究者としても研究を進めさせ ていただいたことを厚く御礼申し上げます。本研究の 先駆けとなる $\mathrm{M}_{12} \mathrm{~L}_{24}$ 球状錯体合成の研究を展開された、 徳島文理大学の富永昌英博士には貴重なご助言をいただ き大変感謝しております。生体関連の応用に関しては、 名古屋市立大学 - 分子研の加藤晃一博士、矢木内海真穂 博士、山口拓実博士、名城大学の栗本英治博士、理研の 山口芳樹博士、がん研究所の芝清隆博士、松村幸子博士、 大阪大学の内山 進博士、野田勝紀博士、京都大学の杉 山正明博士と共同で研究させていただきました。単結晶 $\mathrm{X}$ 線構造解析に関しては、日本大学の尾関智二博士、高 輝度光科学研究センターの熊坂 崇博士、水野伸宏博士、
理研の高田昌樹博士、Jyväskylä 大学の Kari Rissanen 博 士、Jens Bunzen 博士と共同で研究させていただきまし た。質量分析に関しては、徳島文理大学の山口健太郎博 士、清 悦久博士、理研の越野広雪博士、本郷やよい博 士と共同で研究させていただきました。無機ナノ材料の 解析に関しては、京都大学の寺村謙太郎博士、朝倉博行 博士、千葉大学の大場友則博士、森田 剛博士と共同で 研究させていただきました。計算シミュレーションに関 しては、米谷 慎博士、山口智彦博士と共同で研究させ ていただきました。錯体の高次集積に関しては、Lehigh 大学の Tianbo Liu 博士と共同で研究させていただきまし た。末尾ながら特筆すべきこととして、本研究成果が得 られたことは熱心に研究に励んでくださった学生諸氏の 努力によるものです。一人一人のお名前を挙げることが スペース上できず申し訳ありませんが、改めて心より感 謝申し上げます。

実験の実施にあたつては、SPring-8 BL01B1, BL02B1， BL26B1, BL26B2, BL38B1, BL40XU, BL41XU, BL45XU ビームライン、KEK PF BL1A, PF BL10C, PF BL17A, PFAR, NW2A, PF-AR NW12A, PF-AR NE3A ビームライ ン、AS MX1, MX2 ビームライン、J-PARC MLF BL15 TAIKAN ビームライン、ILL HFR D22 ビームライン、分 子研ナノテクノロジープラットホーム (920 MHz NMR)、 理研横浜 NMR 施設、徳島文理大学香川薬学部中央機器 室、千葉大学共用機器センター、東京大学超微細リソグ ラフィー・ナノ計測拠点、東京大学大学院理学系研究科 化学専攻有機元素分析室にて、貴重な測定時間を使用さ せていただきました。また、日本電子(株)、ブルカー・バ イオスピン(株)、ブルカー・ダルトニクス(株)、日本ウォー ターズ(株)、アジレント・テクノロジー(株)、サーモフィッ シャーサイエンティフィック株、(株)島津製作所、日本分 光(株)、(株アサイラムテクノロジー、(株)アンンパール・ ジャパン、日本シイベルヘグナー(株にてて、最新鋭の測定 装置を使用させていただきました。研究の促進にご高配 賜りありがとうございました。

世界最大級の一義構造の分子の合成、構造決定、分 子生物学や無機材料への応用への展開は、とても一つの 研究グループだけで実施できるものではありませんでし た。お名前をご紹介できなかった方々も含め、沢山の研 究者・学生の方々に助けられ、また数え切れないほどの 装置から得られた実験結果を総合的に考察することで初 めて成果につながりました。この場を借りて厚く御礼申 し上げます。

\section{文献}

1 ) M. Fujita, Y. J. Kwon, S. Washizu, K. Ogura, J. Am. Chem. Soc., 116, 1151-1152 (1994). 
2 ) M. Tominaga, K. Suzuki, M. Kawano, T. Kusukawa, T. Ozeki, S. Sakamoto, K. Yamaguchi, M. Fujita, Angew. Chem. Int. Ed., 43, 5621-5625 (2004).

3 ) K. Suzuki, M. Tominaga, M. Kawano, M. Fujita, Chem. Commun., 1638-1640 (2009).

4 ) K. Yamaguchi, J. Mass Spectrom., 38, 473-490 (2003).

5 ) Q.-F. Sun, J. Iwasa, D. Ogawa, Y. Ishido, S. Sato, T. Ozeki, Y. Sei, K. Yamaguchi, M. Fujita, Science, 328, 1144-1147 (2010).

6 ) J. Bunzen, J. Iwasa, P. Bonakdarzadeh, E. Numata, K. Rissanen, S. Sato, M. Fujita, Angew. Chem. Int. Ed., 51, 3161-3163 (2012).

7 ) D. Fujita, H. Yokoyama, Y. Ueda, S. Sato, M. Fujita, Angew. Chem. Int. Ed., 54, 155-158 (2015)

8 ) M. Yoneya, T. Yamaguchi, S. Sato, M. Fujita, J. Am. Chem. Soc., 134, 14401-14407 (2012).

9 ) M. Yoneya, S. Tsuzuki, T. Yamaguchi, S. Sato, M. Fujita, ACS Nano, 8, 1290-1296 (2014).

10 ) Q.-F. Sun, T. Murase, S. Sato, M. Fujita, Angew. Chem. Int. Ed., 50, 10318-10321 (2011).

11 ) Q.-F. Sun, S. Sato, M. Fujita, Angew. Chem. Int. Ed., 53, 1351013513 (2014).

12 ) Q.-F. Sun, S. Sato, M. Fujita, Nature Chem., 4, 330-333 (2012).

13 ) K. Harris, Q.-F. Sun, S. Sato, M. Fujita, J. Am. Chem. Soc., 135, 12497-12499 (2013).

14 ) D. Fujita, A. Takahashi, S. Sato, M. Fujita, J. Am. Chem. Soc., 133, 13317-13319 (2011).

15 ) S. Sato, Y. Ishido, M. Fujita, J. Am. Chem. Soc., 131, 6064-6065 (2009).

16 ) M. Tominaga, K. Suzuki, T. Murase, M. Fujita, J. Am. Chem. Soc., 127, 11950-11951 (2005)

17 ) S. Sato, J. Iida, K. Suzuki, M. Kawano, T. Ozeki, M. Fujita, Science, 313, 1273-1276 (2006).

18 ) K. Suzuki, J. Iida, S. Sato, M. Kawano, M. Fujita, Angew. Chem. Int. Ed., 47, 5780-5782 (2008).

19 ) K. Suzuki, K. Takao, S. Sato, M. Fujita, J. Am. Chem. Soc., 132, 2544-2545 (2010).
20 ) T. Murase, S. Sato, and M. Fujita, Angew. Chem. Int. Ed., 46, 51335136 (2007).

21 ) T. Murase, S. Sato, M. Fujita, Angew. Chem. Int. Ed., 46, 10831085 (2007).

22 ) T. Kikuchi, T. Murase, S. Sato, M. Fujita, Supramol. Chem., 20, 81-94 (2008).

23 ) Q.-F. Sun, S. Sato, M. Fujita, Chem. Lett., 40, 726-727 (2011).

24 ) K. Suzuki, M. Kawano, S. Sato, M. Fujita, J. Am. Chem. Soc., 129, 10652-10653 (2007).

25 ) D. Fujita, K. Suzuki, S. Sato, M. Yagi-Utsumi, E. Kurimoto, Y. Yamaguchi, K. Kato, M. Fujita, Chem. Lett., 41, 313-315 (2012).

26 ) D. Fujita, K. Suzuki, S. Sato, M. Yagi-Utsumi, Y. Yamaguchi, N. Mizuno, T. Kumasaka, M. Takata, M. Noda, S. Uchiyama, K. Kato, M. Fujita, Nature Commun., 3, 1093 (2012).

27 ) K. J. C. Van Bommel, A. Friggeri, S. Shinkai, Angew. Chem. Int. Ed., 42, 980-999 (2003).

28 ) K. Suzuki, S. Sato, M. Fujita, Nature Chem., 2, 25-29 (2010).

29 ) T. Ichijo, S. Sato, M. Fujita, J. Am. Chem. Soc., 135, 6786-6789 (2013).

30 ) K. Suzuki, K. Takao, S. Sato, M. Fujita, Angew. Chem. Int. Ed., 50, 4858-4861 (2011).

31 ) N. Kamiya, M. Tominaga, S. Sato, M. Fujita, J. Am. Chem. Soc., 129, 3816-3817 (2007).

32 ) T. Kikuchi, S. Sato, M. Fujita, J. Am. Chem. Soc., 132, 1593015932 (2010).

33 ) K. Takao, K. Suzuki, T. Ichijo, S. Sato, H. Asakura, K. Teramura, K. Kato, T. Ohba, T. Morita, M. Fujita, Angew. Chem. Int. Ed., 51, 5893-5896 (2012).

34 ) K. Sano K. Shiba, J. Am. Chem. Soc., 125, 14234-14235 (2003).

35 ) M. Ikemi, T. Kikuchi, S. Matsumura, K. Shiba, S. Sato, M. Fujita, Chem. Sci., 1, 68-71 (2010).

36 ) T. Kikuchi, S. Sato, D. Fujita, M. Fujita, Chem. Sci., 5, 3257-3260 (2014).

\section{Profile}

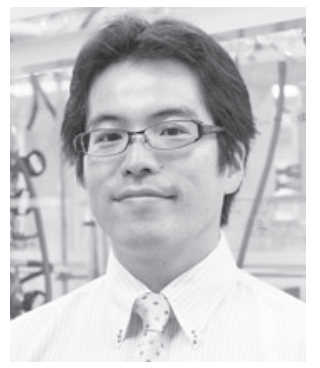

佐藤 宗太

東北大学原子分子材料科学高等研究機構 (WPI-AIMR) 准教授 博士 (理学)

[経歴］ 2000 年東京大学理学部卒業、2005 年東京大学大学院理学系研究科博士課程修了、同 年東京大学大学院工学系研究科応用化学専攻・助手、2007 年同助教、2010 年同講師、2013 年東北大学原子分子材料科学高等研究機構 - 准教授、同年 JST, ERATO, 磯部縮退 $\pi$ 集積プロ ジェクト・グループリーダー (兼任)

[専門] 錯体化学、有機化学 